\title{
Mucositis Effect on Quality of Life of Hospitalized Children with Cancer Who Received Chemotherapy
}

\author{
Sri Hendrawati, Ikeu Nurhidayah, Henny Suzana Mediani, Ai Mardhiyah, \\ Nenden Nur Asriyani Maryam \\ Faculty of Nursing Universitas Padjadjaran, Bandung, Indonesia \\ Corresponding Email: sri.hendrawati@unpad.ac.id
}

Submitted: 27-09-2018 Accepted: 08-02-2019 Published: 11-04-2019

\begin{abstract}
Mucositis is very common in children with cancer who received chemotherapy. Mucositis in children renders other health problems such as pain, eating problems, insomnia, and emotional problems that directly determine children's quality of life. The purpose of this research was to identify how the effects of mucositis on quality of life in children with cancer who received chemotherapy. The method used in this research is correlative descriptive analytic with cross-sectional design. Samples taken in this research utilized consecutive sampling technique. The children with cancer who met the inclusion criteria were approached to participate in this research. Sixty children with cancer hospitalized in Dr. Hasan Sadikin Hospital Bandung recruited in this research. Mucositis identification utilized Oral Assessment Guide (OAG). Data quality of life (QoL) would be assessed with PedsQoL Cancer Module 3.0. Data were analyzed by Chi-square correlation test. There are 53 children $(88.3 \%)$ who experienced mucositis. In contrast, there are only 7 children who didn't experience mucositis $(11.7 \%)$. Based on this survey, there are 37 children $(61.7 \%)$ have bad quality of life. Otherwise, 23 children $(38.3 \%)$ have good quality of life. This research found that there is a significant relationship between mucositis and QoL of children with cancer. Accordingly, the relationship between mucositis cases and QoL of children with cancer valued at $0.006(p<0.05)$. Mucositis cause low QoL in children with cancer compared to them without mucositis. Nurse should increase nursing care for children with mucositis as the side effect of chemotherapy. Suggested efforts are to prevent mucositis complication that will impact QoL, such as giving oral care with honey, keeping humid oral mucosa, and preventing infection.
\end{abstract}

Keywords: Chemotherapy, children with cancer, mucositis, quality of life. 
Sri Hendrawati: Mucositis Effect on Quality of Life of Hospitalized Children with Cancer

\section{Introduction}

Cancer is a group of abnormal cells formed by growing, unlimited and uncoordinated cells unrelated to surrounding cells and physiologically malfunctioned (Price \& Wilson, 2013). This abnormal group of cells is produced by factors; genetic and surroundings (Baggot et al., 2002). It changes cell metabolism and destructs body's physiological functions (Price \& Wilson, 2013).

Nowadays, cancer is a serious and threatening disease for children around the world. The threat is immense according to recent numbers of new cancer sufferers. National Cancer Institute or NCI (2009) stated that there are more than six millions new cancer sufferers every year. Additionally, NCI (2009) assumed four percent cancer were in children.

Children with cancer is a growing problem in Indonesia (Sujudi, 2002). According to Gatot (2008), the prevalence of cancer in children in Indonesia hits four percent and it means four percents of birth rate in Indonesia will suffer cancer. Nowadays, cancer is included into the top ten of lethal cause of children mortality in Indonesia (Kemenkes RI, 2017). This fact is supported by the data from National Hospital (RSUPN) Dr. Cipto Mangunkusumo Jakarta which also showed that cancer is included into the top ten of lethal cause of children mortality in Indonesia. The data from Dr. Hasan Sadikin Bandung Hospital in 2010 showed similar fact; that cancer is the first cause for children mortality in this hospital and chemotherapy in children with cancer is the most common case (Departemen Ilmu Kesehatan Anak RSUP Dr. Hasan Sadikin Bandung, 2016).

Cancer in children should be treated adequately. NCI (2009) stated that cancer treatment in children includes chemotherapy, bio-therapy, radiological therapy, cyrotherapy and spinal cord transplant peripheral blood stem cell. The most applied therapy in cancer for children is chemotherapy. Chemotherapy does not only provides a good impact, but also provides adverse side effects for children, both physically and psychologically. Side effects that occur depend on the type and dose of chemotherapy drugs used. Chemotherapy causes children to be susceptible to mucositis, infections, bleeding, fatigue, lethargy, hair loss, nausea, vomiting, diarrhea, constipation, decreased appetite, neuropathy, haemorrhagic cystitis, urinary retention, moonface, sleep disorders, and an effect on fertility adult (National Cancer Institute, 2010; Hockenberry et al., 2010). The most common side effect experienced by children is mucositis. This often interferes with the daily activities of the child, including school (van Vliet, Harmsen, de Bont, \& Tissing, 2010). Mucositis is an oral mucosa membrane inflammatory and ulceration. Oral Mucosa consists of mucosa cells that incessantly and promptly divided. Chemotherapy disturbs mucosa cell division and it leads to mucositis. Mucositis has negative effects for children (Cancer Care Nova Stovia (CCNS), 2008).

According to a study by United Kingdom Children's Cancer Study Group and Pediatric Oncology Nurses Forum or UKCCSG-PONF in 2006, the mucositis prevalence among children is around $30-40 \%$. Another study by Cancer Care Nova Stovia (CCNS) in 2008, stated that mucositis prevalence was even bigger, it was $45-80 \%$. In Indonesia, studies on mucositis prevalence are yet unpopular. Despite, Nurhidayah, Sholehati, and Nuraeni (2013) from Dr. Hasan Sadikin Hospital Bandung, revealed that most respondents suffered from mucositis $(67.9 \%)$.

Mucositis in children renders other health problems; pain, insomnia, eating problems and emotional problems that directly determine children's quality of life. A study by Cheng et al. (2012) on mucositis effects to children's quality of life comprised 140 children of 6-18 years old in China disclosed decrease of quality of life based on problems of eating, gulping, drinking, sleeping and talking. In Indonesia, studies on quality of life of children with cancer are yet unpopular. Despite, Irmawati, Irwanto, and Cahyadi (2013) from hospital in Surabaya identified the quality of life in children with cancer using PedQoL 3.0, this studies revealed that the scores from children for treatment anxiety, cognitive problem and total scale was high. The subscale procedure anxiety, worry, and pain-hurt had low-scores for both children, and the overall scores was 
61-81. Another study by Cheng (2008) in Hong Kong, revealed $80 \%$ oral mucositis by cancer therapy in adults resulted disturbance to patients' daily activities and psycho-social functions. The study utilized Chinese Version Functional Assessment of Cancer Therapy General Questionares (Ch-FACT-G). The result illustrated correlation between mucositis effects to children's quality of life; social, emotional, and physical life. Quality of life should be considered as a significant consideration for cancer treatment in children. Dr. Hasan Sadikin Hospital Bandung is the reference hospital for children cancer case in West Java. A study on children cancer case in this hospital disclosed that most children were suffering from pain caused by mucositis. This pain leads children to experience gulping, drinking, sleeping and speaking problems. Pre-study showed similar result, most parents claimed their children suffered from emotional (easily disturbed) and physical problems as well as eating and speaking problems (articulation).

It's very important for nurse to understand effects of mucositis to the quality of life of children with cancer. This understanding helps nurses to decide properly nursing interventions for children regarding their condition. Consequently, mucositis effects on quality of life of children with cancer is essential to be studied. The objective of this study is to identify mucositis effect on quality of life of children with cancer.

\section{Method}

This study design used correlative descriptive analytic with cross sectional design (Polit \& Beck, 2008). This method aimed to recognize how mucositis determines the quality of life of children with cancer. Hypotheses formulated in this research are mucositis effect to quality of life of children with cancer is exist. The object of this research is children with cancer in children care centre in Dr. Hasan Sadikin Hospital Bandung which has average attendance of 30 children each month. Samples were obtained in this research using a consecutive sampling method. The inclusive criteria were: 1) the object of this research is children with cancer aged 2-18 years, 2) children were in ongoing treatment in Dr. Hasan Sadikin Hospital Bandung, and 3) children were in stable hemodynamic conditions. While the exclusive criteria is children with nasofaring cancer stage $3-4$; the children in this stage are obstructed to open their mouth, therefore it's almost impossible to assess their mucositis. The time range of this research is 3 months from July 2015 to September 2015 with 60 samples of children with cancer hospitalized in Kenanga I and II Children Care Center in Dr. Hasan Sadikin Hospital Bandung.

Mucositis identification in children utilized Oral Assessment Guide (OAG). This instrument was designed by Eilers, Berger, and Petersen (1988); Dodd (2004); and Eilers (2004). This assessment is considered as affable for nurses to assess mucositis in children. OAG consists of eight assessment parameters, namely objective assessment to see the status of mucous membranes, lip, tongue, gingival, and tooth conditions; as well as functional and subjective studies to assess sound; salivary gland function, and swallowing ability. The assessment is described in score 1 to 3 for each parameter. Score one (1) if normal, score two (2) if there is a moderate change, and score three (3) if there are severe changes. The method of OAG assessment is done by observation, visual examination, palpation, and auditory. The lowest mucositis score is 8 and the highest score is 24 .

Data of children quality of life would be assessed with PedsQoL (Pediatric's Quality of Life) Cancer Module 3.0 designed by Varni, Burwinkle, dan Seid (2005). This instrument is proven for its reliability and validity and had been translated into 69 languages. The PedQoL Cancer Module 3.0 instrument is specifically used to assess the quality of life of children with cancer. The PedQoL Cancer Module 3.0 includes eight domains, namely pain and hurt, nausea, procedural anxiety, treatment anxiety, worry, cognitive problems, perceived physical appearance, and communication. Assessment is given with a score of 0 to 4 on each item in question. Each answer to the question is converted to a scale of 0 to 100 for standard interpretation, namely the score $0=100$, score $1=75$, score $2=50$, score $3=25$, and score $4=0$. The total 
score is calculated by adding the score of the question answers divided by the number of questions answered on all domains.

Research of nursing must be tied to these codes of conduct; self determination, anonymity and confidentiality, protection from discomfort, beneficence and justice (Polit \& Beck, 2008). This study has received ethical approval from the Health Research Ethics Committee Dr. Hasan Sadikin Hospital Bandung with a number of ethical clearance LB.04.01/A05/EC/154/V/2015. The researcher would take sample of data in accordance with procedures for administrative and research permission.

Samples of data would be processed with statistical analysis on result of study. Data analysis will use univariat dan bivariat analysis. Univariat analysis aimed to analyze research variables descriptively. Descriptive analysis describes mucositis cases and quality of life of children with cancer using mean value, standard deviation, and frequency distribution. Univariat result data showed here as frequency and percentage. Bivariat analysis was completed to examine hypothesis with proportion differentiation test using correlative statistical test (Chisquare correlation test). Moreover, the latter employed to determine relation between independent and dependent variables. This analysis employs meaning degree $\alpha \quad 5 \%$ $(p<0.05)$. If only $p<\alpha$, therefore hypothesis is rejected.

\section{Result}

This research was completed in Kenanga Room I and II Children Care Center in Dr. Hasan Sadikin Hospital Bandung in 3 months since July to September 2015. There were 60 hospitalized children with cancer and earned chemotherapy in both rooms.

Mucositis case of hospitalized children with cancer in Children Care Center Kenanga Room I and II Dr. Hasan Sadikin Hospital Bandung is drawn in table below.

Table 1 Mucositis Case of Hospitalized Children with Cancer in Children Care Center $(n=60)$

\begin{tabular}{lcc}
\hline \multicolumn{1}{c}{ Mucositis Case } & Frequency (n) & Percentage (\%) \\
\hline Non-Mucositis & 7 & 11.7 \\
Mucositis & 53 & 88.3 \\
\hline
\end{tabular}

Table 2 Quality of Life of Hospitalized Children with Cancer in Children Care Center $(n=60)$ according to PedQoL Cancer Module 3.0

\begin{tabular}{lccc}
\hline \multicolumn{1}{c}{ Quality of Life } & Value Mean & Deviation Standard & $\begin{array}{c}\text { Minimum Score - } \\
\text { Maximum Score }\end{array}$ \\
\hline Total Score & 49.23 & 21.73 & $11.54-94,44$ \\
Pain and Hurt & 48.75 & 35.26 & $0.00-100.00$ \\
Nausea & 39.50 & 33.59 & $0.00-100.00$ \\
Procedural Anxiety & 48.61 & 39.78 & $0.00-100.00$ \\
Treatment Anxiety & 71.39 & 33.63 & $0.00-100.00$ \\
Worry & 33.75 & 38.92 & $0.00-100.00$ \\
Cognitive Function & 50.23 & 25.49 & $0.00-100.00$ \\
Physical Function & 58.33 & 36.47 & $0.00-100.00$ \\
Communication Function & 54.44 & 33.52 & $0.00-100.00$ \\
\hline
\end{tabular}

Table 3 Quality of Life of Hospitalized Children with Cancer in Children Care Center $(n=60)$ according to PedQoL Cancer Module 3.0

\begin{tabular}{lcc}
\hline \multicolumn{1}{c}{ Quality of Life } & Frequency (n) & Percentage (\%) \\
\hline Good Quality of Life & 23 & 38.3 \\
Bad Quality of Life & 37 & 61.7 \\
\hline
\end{tabular}


Sri Hendrawati: Mucositis Effect on Quality of Life of Hospitalized Children with Cancer

Tabel 4 Mucositis Correlation with Quality of Life of Hospitalized Children with Cancer in Children Care Center $(n=60)$

\begin{tabular}{cc}
\hline Variables & Quality of Life PedQoL Cancer Module 3.0 \\
\hline Mucositis Case & $\mathrm{p}=0.006$ \\
\hline
\end{tabular}

Table 1 showed that most children with cancer who received chemotherapy experience mucositis as many as 53 people $(88.3 \%)$. As a fraction as many as 7 people $(11.7 \%)$ had no mucositis.

Quality of life (QoL) of hospitalized children with cancer in Children Care Center Kenanga Room I and II Dr. Hasan Sadikin Hospital Bandung is drawn in table below.

Based on table 2, questionnaire PedQoL Cancer Module 3.0 expose quality of life based on treatment anxiety experienced by children with cancer attain highest value mean (71.39). Quality of life with high mean value in addition to aspects of treatment anxiety also followed by aspects of perceived physical appearance (58.33), communication (54.44), and cognitive problems (50.23). Otherwise, quality of life based on children's worry to face their illness and their medication has lowest value mean of 33.75 , followed by aspects of nausea (39.50), procedural anxiety (48.61), and pain and hurt (48.75).

Based on table 3, there are 37 children $(61.7 \%)$ have bad quality of life. Otherwise, 23 children (38.3\%) have good quality of life. Mucositis correlation with quality of life of hospitalized children with cancer in Children Care Center Kenanga Room I and II Dr. Hasan Sadikin Hospital Bandung drawn in table below.

Based on table 4, there's such a significant relationship between mucositis and quality of life of children with cancer. Accordingly, the relationship between mucositis cases and quality of life of children with value $p$ of $0.006(p<0.05)$ based on quality of life PedQoL Cancer Module 3.0.

\section{Discussion}

\section{Mucositis Cases in Children with Cancer}

Patients who earned chemotherapy were risked $20 \%-40 \%$ to experience of mucositis. Oral mucositis symptoms consist of objective symptom (erythema, lesions, and edema), subjective changes (pain, sensitivity and dry feeling) and functional adjustment (changes of voice, gnawing and swallowing) (Potting et al., 2005). Mucositis caused by injured cells. Injured cells ensued by drugs; chemotherapy side effects, chemicals, infections, traumas or irritated lattice caused by mechanic stuffs (for example, contact between mucosa and stuffs as tooth brush).

This result shows that almost all children with cancer who earned chemotherapy experienced mucositis. There are 53 children out of $60(88.3 \%)$ who experienced mucositis. In contrast, there are only 7 children who didn't experience mucositis (11.7\%). This research synchronizes former research by Nurhidayah, Sholehati, and Nuraeni (2013) who showed that most children with cancer $(67.9 \%)$ who earned chemotherapy experienced mucositis. According to a study by United Kingdom Children's Cancer Study Group and Pediatric Oncology Nurses Forum or UKCCSG-PONF in 2006, mucositis prevalence in children with cancer reach $30-40 \%$. Another study by Cancer Care Nova Stovia (CCNS) in 2008, revealed bigger probability of mucositis prevalence $(45-80 \%)$.

Mucositis in children with cancer could be categorized as severe. According to Eilers (2004), mucositis renders various disorders; physiologically and functionally. Physiological disorders caused by mucositis are lesions, ulceration, extra inflammation, pain and infection. Lesions and ulceration caused by mucositis predispose bacterial infection, fungi and virus. This will threat children for its systemic infection risk. In addition, functional disorder caused by mucositis are gnawing, swallowing and speaking obstruction.

This research reveals $88.3 \%$ of children with cancer who earned chemotherapy experienced mucositis. Based on claims by children with cancer who experienced mucositis, there are several disorders entailing. They are soreness, insomnia, eating and emotional problem and activity obstruction. These disorders disturb directly the quality of life of children with cancer. 
Sri Hendrawati: Mucositis Effect on Quality of Life of Hospitalized Children with Cancer

\section{Quality of Life of Children with Cancer}

Severe illnesses emerged in childhood; cancer is one of them, could bring down children's growth and future prospects. Cancer is a severe disease with double effects; the troubling illness itself and side effects of its treatments. Cancers need continuing medication and treatment, one of them is chemotherapy. Severe condition experienced by children costs their physical, psychological and social condition (Bulan, 2009). This cost due to children's maturation process and children growth in each level. Disturbed growth relates children's quality of life.

Continuing chemotherapy for children with cancer will cost physically (easily infected, bleeding, fatigue, lackluster, falling hair, mucositis, sick, constipation, low appetite, neuropathy, hemorrhagic cystitis, urinate retention, moonface, insomnia and fertility for adults). Psychosocial effect is another side effect of continuing chemotherapy. Among them are mood disorder, anxiety, lost confidence, low self esteem, depression and behavioral changes lead to school refusal (Hockenberry et al., 2010). All these are immense for children with cancer. Moreover, their quality of life will decrease to the lowest level.

Based on questionnaire PedQoL Cancer Module 3.0 children with cancer who hospitalized and experienced treatment have low quality of life. Based on this survey, there are 37 children $(61.7 \%)$ have bad quality of life. Otherwise, 23 children $(38.3 \%)$ have good quality of life. This number reveals most children with cancer are in no good quality of life.

Questionnaire PedQoL Cancer Module 3.0 expose quality of life based on treatment anxiety experienced by children with cancer attain highest value mean (71.39). Result of this questionnaire displays anxiety treatment for children with cancer resulted better quality of life compared to other aspects. This aspect comprises treatment for children's anxiety emerged throughout their medication at hospital. Regularity of medication leads to low anxiety throughout their medication at hospital. A similar study conducted by Bariah et al. (2011) in Malaysia also shows that the quality of life aspect in terms of treatment of anxiety has the highest mean value of 81.94. The research of Ji et al. (2011) also shows that quality of life viewed from procedural anxiety has a mean value of 68.02. This indicates that children are experiencing fears about the procedural treatment that undergoes, resulting in decreased quality of life. Quality of life with high mean value in addition to aspects of treatment anxiety also followed by aspects of perceived physical appearance (58.33), communication (54.44), and cognitive problems (50.23).

Otherwise, quality of life based on children's worry to face their illness and their medication has lowest value mean of 33.75. The latter contradicts the previous; in case of facing illness and medication, the children attained lowest score. The children are vulnerable to anxiety of side effects, or their probability of thriving medication. Moreover, the anxiety of recurrence of cancer is also excess their feeling. These factors contribute to lower children's quality of life. In this study, the quality of life with the lowest mean value in addition to the aspects of worry or fear, followed by aspects of nausea (39.50), procedural anxiety (48.61), and pain and hurt (48.75) that show has a worse quality of life when compared with other aspects.

This study is in line with the results of research Fawzy et al. (2013) that conducted in Egypt using the PedQoL Cancer Module 3.0 questionnaire. Research of Fawzy et al. (2013) showed that children with cancer had a poor quality of life with a mean value of 62.29. When viewed from various aspects that shape the quality of life, the research of Fawzy et al. (2013) have similar results with the results of this study where the lowest mean value of quality of life score is in the aspects of worry (44.11), perceived physical appearance (50.6), and procedural anxiety (55.34). While the highest mean value on quality of life score is in communication (75.98) and cognitive problems (72.63).

The similar studies in Brazil also used the PedQoL Cancer Module 3.0 questionnaire (Scarpelli et al., 2008). This study shows that children with cancer have poor quality of life with a mean of 76.41. But in a study in Brazil it shows that the aspect of pain and hurt has a higher value than other aspects with a mean value of 86.47 . This shows that 
Sri Hendrawati: Mucositis Effect on Quality of Life of Hospitalized Children with Cancer

the children are able to adapt to the pain and hurt that felt. The study was supported by research conducted by Tsuji et al. (2011) in Tokyo, Japan, which also showed poor quality of life in children with cancer with a mean of 77.89. In the study of Tsuji et al. (2011), communication aspect has the lowest value when compared with other aspect with mean value equal to 67.03 . Based on this it can be concluded that children with cancer may have obstacles in communication, for example because it is difficult to tell doctors and nurses what is felt, answer questions from doctors and nurses, and difficult to explain the disease to others.

If the value of quality of life in these countries is compared between the mean values of this study conducted in Indonesia, especially in Dr. Hasan Sadikin Hospital Bandung with some studies conducted abroad, including in Thailand, China, Brazil, Japan, Malaysia, and Egypt, the value of total quality of life of children with cancer in Indonesia is much lower when compared with the score of quality of life values in the countries outside. This shows that the quality of life of cancer children in Indonesia is worse when compared with other countries. Thus it is necessary efforts of health workers, especially nurses to be able to improve the quality of life of cancer children in Indonesia in particular. Nurses should be able to provide support to children and families in identifying effective coping strategies so that children and families feel comfortable in chronic conditions experienced by children and can adapt positively to have a better quality of life.

\section{Mucositis Relationship with Children with Cancer Quality of Life}

This study found that there's such a significant relationship between mucositis and quality of life of children with cancer. Accordingly, the relationship between mucositis cases and quality of life of children with value $p$ of $0.006(p<0.05)$ based on quality of life PedQoL Cancer Module 3.0. Mucositis is able to worsen quality of life of children with cancer in comparison with non mucositis case in children with cancer.

This study confirms previous study by Cheng et al. (2012) on mucositis effects on quality of life of children and teenager as it taken from 140 samples with age range of 6-18 in China. Cheng's study found that there's generic decrease of quality of life among children and teenagers with cancer. Common symptoms emerged as eating, swallowing, drinking, sleeping, oral problem. Another study by Cheng (2008) in Hong Kong revealed oral mucositis, caused by cancer therapy, among 80 adult patients had disturbed their daily activities and social life. The result confirmed positive line of mucositis effects on social life, emotional life and physical fitness among children. The conclusion is, the children who experience mucositis were disturbed physically, emotionally and socially. The disturbs lead to a worsened quality of life.

In this matter, nurses should actively foster children with cancer to minimize the occurrence possibility of mucositis caused by chemotherapy. Possible treatments are oral cares; oral cleanliness to protect oral cavity, to prevent plaque emergence on teeth, to keep mucosa humid, to keep mucosa integrated, to keep away infection, to prevent oral ulceration and to maintain other oral functions. Oral mucosa damage is unavoidable, but it could be minimized by preventing infection.

Moreover, the children with heavy side effects should experience good quality of life. They should be physically, emotionally good and excel their social and academic life. One of prime efforts, to boost their quality of life, is children ought to learn their course at the hospital as well as to interact and earn their emotional therapy to help them to cope with the side effects.

\section{Conclusion}

This research found that there is a significant relationship between mucositis case in children with cancer with their quality of life explained by $p$ value $=0.006(p<0.05)$ based on quality of life PedQoL Cancer Module 3.0. Therefore, significant relationship between mucositis with quality of life in children with cancer is confirmed. Mucositis cause low quality of life in children with cancer compared to them without mucositis.

Nurse, in this matter, should increase 
Sri Hendrawati: Mucositis Effect on Quality of Life of Hospitalized Children with Cancer

cares for children with cancer to minimize mucositis probability as side effect of chemotherapy. Suggested efforts are cares for oral cleanliness to maintain healthiness of oral cavity, preventing surface plaques on children teeth to ward off dental caries, keeping humid oral mucosa, maintaining mucosa integrity, preventing infection, preventing oral ulceration and maintaining oral function. Oral mucosa damage is unavoidable. However, prevention steps to ward off infection could minimize damage to oral functions. Additionally, profound side effect of medication shouldn't prevent children to gain good life; physical, emotional, social and academic. To provide them opportunities to learn and to interact while they are hospitalized and to give them extra sessions of psycho-therapy would help them to cope with medication's side effects.

\section{References}

Baggot, R.B., Kelly, K.P., Fochtman, D., \& Folley, G. (2001). Nursing care of children and adolescent with cancer (3rd edition). Pennsylvania: W.B Saunders Company.

Bariah, S., Roslee, R., Zahara, A.M., \& Norazmir, M.R. (2011). Nutritional status and Quality of Life (QoL) studies among leukemic children at pediatric institute, Hospital Kuala Lumpur, Malaysia. Asian Journal of Clinical Nutrition, 3(2), 62-70.

Bulan, S. (2009). Faktor-faktor yang berhubungan dengan kualitas hidup anak thalasemia beta mayor. . (Factors related to the quality of life of children with beta thalassemia major). Tesis. Universitas Diponegoro

Cancer Care Nova Stovia. (2008). Best practice guidelines for the management of oral complications from cancer therapy. California: Nova Stovia Government. Diperoleh melalui www.cancercare.ns.ca tanggal 10 Januari 2011.

Cheng, K.K. (2008). Association of plasma methotrexate, neutropenia, hepatic dysfunction, nausea/vomiting and oral mucositis in children with cancer. European Journal of Cancer Care, 17, 306-311.

Cheng, K.K., Lee, V., Li, C.H., Yuen, H.L., \& Epstein, J.B. (2012). Oral mucositis in pediatric and adolescent patients undergoing chemotherapy: The impact of symptom on quality of life. Support Care Cancer, 20(10), 2335-42. doi: 10.1007/s00520-011-1343-1.

Departemen Ilmu Kesehatan Anak RSUP Dr. Hasan Sadikin Bandung. (2016). Data pasien anak dengan kanker tahun 2016. (Data on pediatric patients with cancer, 2016)

Dodd, M.J. (2004). The pathogenesis and characterization of oral mucositis associated with cancer therapy. Oncology Nursing Forum, 31(4), 5-12.

Eilers, J., Berger, A.M., \& Petersen, M.C. (1988). Development, testing and application of oral assessment guide. Oncology Nursing Forum, 15, 325-330.

Eilers, J. (2004). Nursing intervention and supportive car for the prevention and treatment of oral mucositis associated with cancer treatment. Oncology Nursing Forum, 31(4), 13-28.

Fawzy, M., Saleh, M., El-Wakil, M., Monir, Z., \& Eltahlawy, E. (2013). Quality of Life in Egyptian children with cancer. Journal of Cancer Therapy, 4, 1256-1261.

Gatot, D. (2008). Deteksi dini kanker anak. (Early detection of childhood cancer). Diperoleh dari http://www.dinkesjabar.go.id/ info/deteksi_dini_kanker_anak/html tanggal 12 Desember $20 \overline{10}$.

Hockenberry, M.J., \& Wilson, D. (2009). Wong's essential of pediatric nursing (8th edition). Missouri: Mosby Company.

Irmawati, M., Irwanto, \& Cahyadi, A. (2012). Penilaian kualitas hidup anak penderita kanker (Assessment of quality of life in cancer children). Jurnal Ners, 7(2), 148-152.

Ji, Y., Chen, S., Li, K., Xiao, N., Yang, X., Zheng, S., \& Xiao, X. (2013). Measuring 
Sri Hendrawati: Mucositis Effect on Quality of Life of Hospitalized Children with Cancer

health-related quality of life in children with cancer living in mainland China: Feasibility, reliability and validity of the Chinese mandarin version of PedsQL 4.0 Generic Core Scales and 3.0 Cancer Module. Health and Quality of Life Outcomes, 9, 103. Available at: http:// www.hqlo.com/content/9/1/103.

Kementrian Kesehatan RI. (2017). Situasi penyakit kanker. (Cancer situation). Retrieved from www.depkes.go.id/resources/ download/pusdatin/infodatin/infodatinkanker.pdf

National Cancer Institute. (2010). Surveillance, epidemiology and end result (SEER). Diperoleh melalui www.seer.cancer. gov/canque/incidence.html tanggal $11 \mathrm{Mei}$ 2011.

(2009). A snapshot of pediatric cancer. Diperoleh melalui http:// www.cancer.gov/aboutnci/servingpeople/ cancer-snapshot tanggal 10 Januari 2011.

Nurhidayah, I., Sholehati, S., \& Nuraeni, A. (2013). Skor mukositis pada anak dengan kanker yang sedang menjalani kemoterapi di RSUP Dr. Hasan Sadikin Bandung. (Mucositis score in children with cancer who are undergoing chemotherapy at RSUP Dr. Hasan Sadikin Bandung). Jurnal Keperawatan Soedirman, 8(1), 1-13.

Polit, D.F., \& Beck, C.T. (2008). Nursing research: Generating and assessing evidence for nursing practice (8th edition). Philadelphia: Lippincott Williams \& Wilkins.

Potting C.M.J, Uitterhoeve, R., Reimer, W.S., \& Achterberg, T.V. (2006). The effectiveness of commonly used mouthwashes for the prevention of chemotherapy-induced oral mucositis: A systematic review. European Journal of Cancer Care, 15(1), 431-439.
Price, S.A., \& Wilson, L.M. (2013). Patofisiologi konsep klinis proses-proses penyakit (Edisi VI). (Pathophysiology of the clinical concept of disease processes (VI Edition)). Jakarta: EGC.

Scarpelli, A. C., Paiva, S. M., Pordeus, I. A., Ramos-Jorge, M. L., Varni, J. W., \& Allison, P. J. (2008). Measurement properties of the Brazilian version of the Pediatric Quality of Life Inventory (PedsQL ${ }^{\mathrm{TM}}$ ) cancer module scale. Health and Quality of Life Outcomes, 6(7). doi:10.1186/1477-7525-6-7.

Sujudi, A. (2002). Kanker anak bisa disembuhkan. (Childhood cancer can be cured). Diperoleh dari www.republika.co.id tanggal 14 Januari 2011.

Tsuji, N., Kakee, N., Ishida, Y., Asami, K., Tabuchi, K., Nakadate, H., Iwai, T., et al. (2011). Validation of the Japanese version of the Pediatric Quality of Life Inventory (PedsQL) Cancer Module. Health and Quality of Life Outcomes, 9(22). Available at: http:// www.hqlo.com/content/9/1/22.

UKCCSG-PONF. (2006). Mouth care for children and young people with cancer: evidence based guidelines. Mouth Care Guidelines Report, Version 1, Feb 2006. Diperoleh melalui www.ukccsg.uk tanggal 10 Januari 2011.

Van Vliet, M.J., Harmsen, H.J.M., de Bont, E.S.J.M., \& Tissing, W.J.E. (2010). The role of intestinal microbiota in the development and severity of chemotherapy-induced mucositis. PLoS Pathogens, 6(5), 1-7. e1000879.

Varni, J.W., Burwinkle, T.M., \& Seid, M. (2005). The PedsQoL as pediatric patientreported outcome: Reliability and validity of PedQoL in measurement model in 25.000 children. Diperoleh melalui www.rand.org tanggal 20 April 2014. 